\title{
Karyological features and banding patterns in Arachis species belonging to the Heteranthae section
}

\author{
S. C. Silva • M. I. G. Martins • R. C. Santos • \\ A. P. S. Peñaloza • P. A. Melo Filho • \\ A. M. Benko-Iseppon · J. F. M. Valls • R. Carvalho
}

Received: 27 August 2009/ Accepted: 19 February 2010/Published online: 11 April 2010

(C) Springer-Verlag 2010

\begin{abstract}
The section Heteranthae of Arachis is endemic to Brazil, occurring mainly in the semi-arid northeastern region. The section is considered derived within the genus and includes only annual herbs. Most previous cytological evaluations were restricted to chromosome numbers and morphology. The present approach comprised karyomorphological evaluation in 10 accessions from five species of this section, including standard staining and fluorochrome banding [chromomycin A3 (CMA)/4',6-diamidino-2-phenylindole (DAPI)]. All accessions presented diploid
\end{abstract}

\section{S. C. Silva $(\square)$ · M. I. G. Martins}

Mestrado em Melhoramento Genético de Plantas,

Depto. de Agronomia, UFRPE, Recife, PE, Brazil

e-mail: silvokleio@gmail.com

R. Carvalho

Laboratório de Citogenética Vegetal, Departamento de Biologia/

Genética, UFRPE, Recife, PE, Brazil

e-mail: reginaldo.ufrpe@gmail.com

R. C. Santos

Centro Nacional de Pesquisa do Algodão, EMBRAPA,

Campina Grande, PB, Brazil

e-mail: caval@cnpa.embrapa.br

A. P. S. Peñaloza · J. F. M. Valls

Centro Nacional de Pesquisa de Recursos Genéticos e

Biotecnologia, EMBRAPA, Brasília, DF, Brazil

e-mail: valls@cenargen.embrapa.br

\section{P. A. Melo Filho}

Departamento de Agronomia, Universidade Federal Rural

de Pernambuco, UFRPE, Recife, PE, Brazil

e-mail: pericles@depa.ufrpe.br

\section{A. M. Benko-Iseppon}

Departamento de Genética, Universidade Federal de

Pernambuco, UFPE, Recife, PE, Brazil

e-mail: celisep@hotlink.com.br chromosome numbers $(2 n=20)$ with a prevalence of metacentric to submetacentric chromosome morphology. Arachis dardani, Arachis pusilla, and Arachis interrupta presented karyotypic formula $18 \mathrm{~m}+4 \mathrm{sm}$ and satellite type 2, while Arachis sylvestris and Arachis giacomettii presented $16 \mathrm{~m}+4 \mathrm{sm}$ and satellite type 10 . Despite the conserved morphological features, higher diversity was detected in terms of size and number of GC-rich $\left(\mathrm{CMA}^{+}\right)$ heterochromatic blocks among the species; however, all of them were located in the pericentromeric regions. The species A. pusilla presented the highest number of GC-rich blocks, present in all chromosomes of the complement. Based on the data obtained and considering literature data, we suggest that $A$. dardani and A. interrupta occupy a basal position in the group due to their moderate asymmetry and satellite type. At least in A. pusilla, the constitutive heterochromatin seems to have suffered recent modifications of its constitution, in contrast to other species that present pericentromeric $\mathrm{CMA}^{+}$blocks in all chromosomes. A. giacomettii and A. sylvestris are closely related to each other and also similar to the previously studied Arachis seridoensis, revealing two clear-cut subgroups within the section from the karyological point of view.

Keywords Chromosome evolution - Peanut relatives . Heterochromatin · CMA/DAPI

\section{Introduction}

The genus Arachis L. (Fabaceae) comprises about 80 described species restricted to the neotropical region. The distribution of its members ranges from the eastern Andes, southern Amazon, and northern Platine Plain to northwestern Argentina. Among its representatives, 64 species 
occur in Brazil (47 are endemic to this country), 15 are distributed in Bolivia, 14 in Paraguay, 6 extend into Argentina, and 2 into Uruguay. The genus includes nine sections: Trierectoides, Erectoides, Extranervosae, Triseminatae, Caulorrhizae, Procumbentes, Rhizomatosae, Arachis, and Heteranthae (Krapovickas and Gregory 1994; Valls and Simpson 2005). The last two groups are considered derived, since most species are woody, while section Arachis includes woody perennials as well as annual herbs and Heteranthae comprises exclusively annual herbs.

The cultivated peanut (Arachis hypogaea L., section Arachis) is the representative of highest economic importance being the fourth most cultivated oily grain in the world, surpassed only by soybean, cotton, and canola. The peanut seeds may be consumed raw, roasted, and in the form of sweets or pastes (Santos et al. 1997; Fávero 2004). In recent decades, wild relatives of the peanut have received more attention from breeders, with emphasis on both sections Arachis and Heteranthae, due to their possible contribution as gene donors, but also for their potential as forage crops and for other attributes including short reproductive cycle, high potential for fodder use, and cultivation as green fertilizers. For members of the Heteranthae group, the tolerance to drought and ability to grow on poor soils represent the most important features for breeding purposes.

Most previous cytogenetically studied representatives of the genus were diploid with $2 n=2 x=20$, with a few species presenting $2 n=2 x=18$, including Arachis decora, Arachis porphyricalyx, Arachis palustris, and Arachis praecox (Husted 1933, 1936; Lavia 1998). Tetraploids (with $2 n=4 x=40$ ) are known only for A. hypogaea, A. monticula, A. glabrata, A. pseudovillosa, and A. nitida and are considered the result of allopolyploid evolution from $2 n=20$ parental diploids (Krapovickas and Rigoni 1951; Gregory et al. 1973; Fernandez and Krapovickas 1994).

Banding features are known mostly for peanut and related species (section Arachis). For example, Cai et al. (1987) observed pericentromeric heterochromatin in some chromosome pairs of Arachis correntina, Arachis villosa, Arachis cardenasii, Arachis stenosperma, Arachis batizocoi, Arachis monticola, Arachis rigonii and A. hypogaea, a feature not confirmed for this last species (A. hypogaea) in a later study carried out by Raina and Mukai (1999).

Most species previously evaluated with fluorochromes presented $\mathrm{DAPI}^{+}$(AT-rich) pericentromeric heterochromatin, sometimes revealing differences among accessions, as in A. decora (section Arachis) where the accession V9955 presented eight pairs with pericentromeric AT-rich blocks, whereas in the accession W648 all chromosome pairs presented $\mathrm{DAPI}^{+}$pericentromeric bands (Lima et al. 2002).

A single previous report included fluorescent in situ hybridization (FISH) using rDNA $45 \mathrm{~S}$ probe in some
Arachis taxa, revealing that their localization was restricted to the single nuclear organizing region (NOR)-bearing satellited pair (Raina and Mukai 1999), also revealed by CMA $^{+}$ flanking regions. The same authors applied the genomic in situ hybridization (GISH) method to confirm the allotetraploid origin of A. hypogaea and its proximity to A. monticola.

Regarding the section Heteranthae, almost all previous reports (e.g., Fernandez and Krapovickas 1994; Peñaloza and Valls 2005) considered chromosome counts and morphology, revealing $2 n=2 x=20$ for all analyzed species. A single species of the section (Arachis seridoensis, accession V10969) was evaluated with fluorochrome staining, revealing two NOR-associated $\mathrm{CMA}^{+}$blocks in the satellited chromosome pair (Peñaloza and Valls 2005).

The present work yields new cytological evidence regarding the Heteranthae section based on standard chromosome staining as well as fluorochrome staining (CMA/DAPI) in order to reveal intrasectional chromosomal variability and to provide useful information for the understanding of chromosomal evolution and species relationships in this important group.

\section{Materials and methods}

All analyzed accessions were collected in their natural environment and deposited in the Active Peanut Germplasm Bank at Embrapa Genetic Resources and Biotechnology (Brasilia City, Brazil). Prior to sowing, seeds were treated with ethrel $(1 \%)$ and germinated over humid filter paper in gerboxes. After germination, plantlets were transferred to disposable cups with autoclaved soil. Root tips from plantlets or young plants were collected and pretreated with 8-hydroxyquinoline $2 \mathrm{mM}$ for $16 \mathrm{~h}$ at $15^{\circ} \mathrm{C}$ for mitotic arrest. Fixation occurred in Carnoy (ethanol:acetic acid, 3:1, v/v), and samples were stored in deep freezer $\left(-20^{\circ} \mathrm{C}\right)$ for subsequent slide preparation.

Giemsa standard chromosome staining was carried out after Guerra (1983) as described by Benko-Iseppon and Morawetz (2000). Fluorochrome staining with CMA/DAPI followed the procedures proposed by Schweizer (1976), according to the steps described by Deumling and Greilhuber (1982).

The best cells were photographed with a Leica DMLB photomicroscope, using the Leica MPS 48 system with ultraviolet light (UV) and specific filters for the fluorochrome excitation wave lengths $360-390 \mathrm{~nm} \quad$ 4',6-diamidino-2phenylindole (DAPI) and 430-470 nm chromomycin A3 (CMA), and halogen light for standard staining. Fuji ASA100 film was used for both techniques.

For chromosomal measurements, the software Image Tool 3.0 was used. Idiogram construction was based on the analysis of 10 selected metaphase spreads. Chromosome classification followed the nomenclature proposed by 


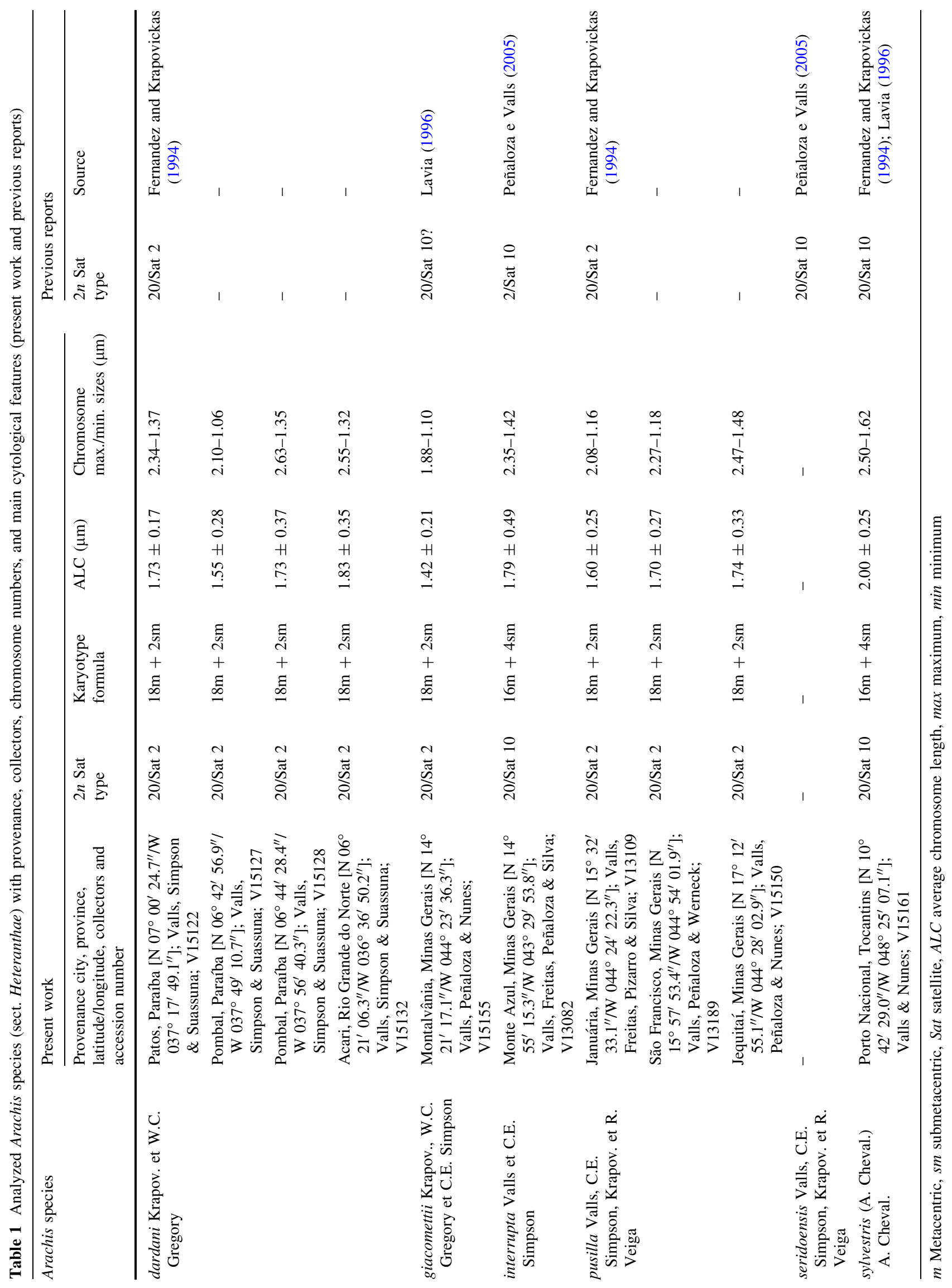


Fig. 1 Prometaphases of some species of the section Heteranthae stained with Giemsa and CMA and DAPI fluorochromes. a A dardani. b A. sylvestris. c $A$. pusilla. d A. dardani. e A. sylvestris f A. pusilla. Arrows indicate heteropycnotic chromosomes. Arrowheads indicate satellites. Bar $5 \mu \mathrm{m}$
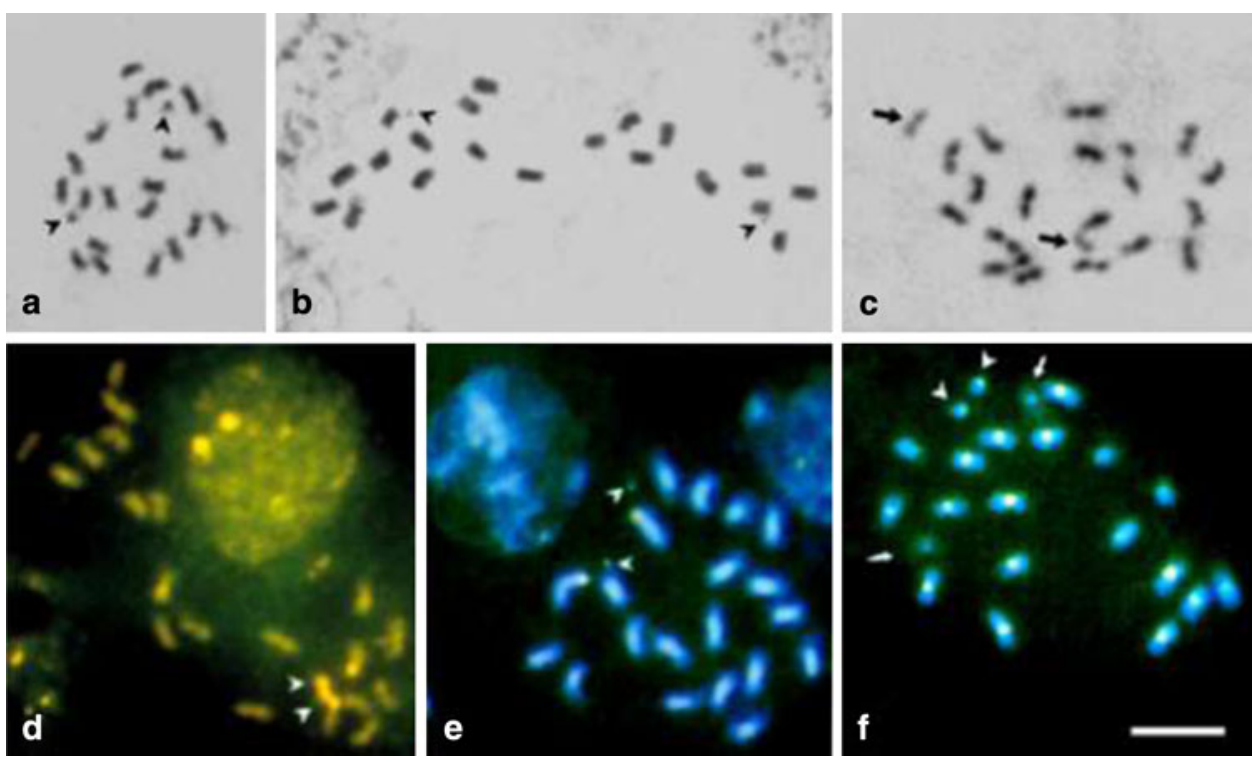

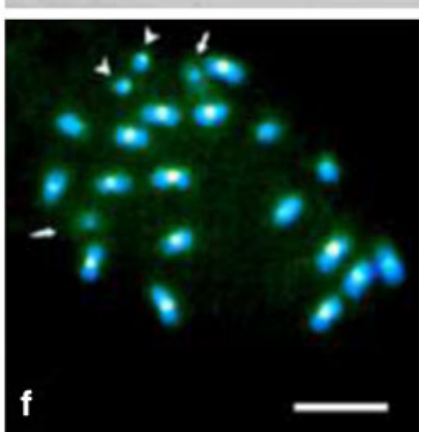

\section{$\mathrm{CMA}^{+} \square$ $\mathrm{DAPI}^{+} \mathrm{O}$}

A. interrupta

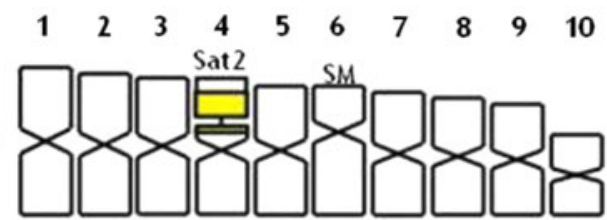

A. dardani

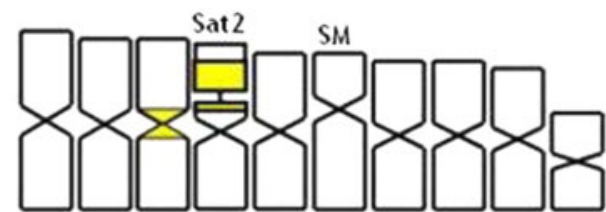

A. pusilla

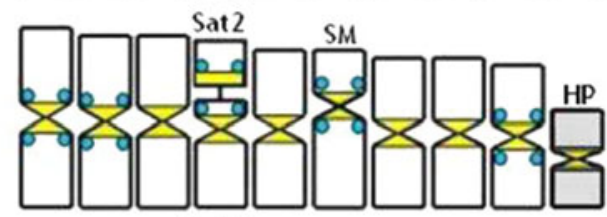

$$
\text { Sat10 }
$$

A. sylvestris

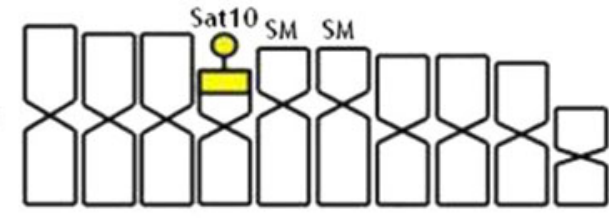

A. giacomettii

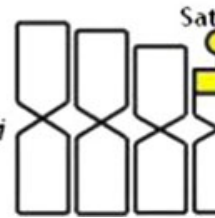

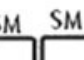

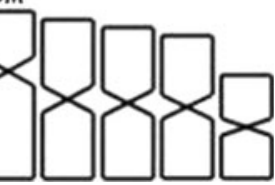

Fig. 2 Idiogram representative of chromosomes indicating GC-rich (yellow) or AT-rich (blue) blocks as revealed by $\mathrm{CMA}^{+}$and $\mathrm{DAPI}^{+}$ fluorochromes. $H P$ Heteropycnotic chromosome, $S M$ submetacentric chromosome, Sat2 satellite type 2, Sat 10 satellite type 10

Guerra (1986) and Morawetz and Samuel (1988). Categorization of peanut satellite types followed Fernandez and Krapovickas (1994).

\section{Results}

All the analyzed accessions presented diploid number $2 n=2 x=20$ (Table 1, Fig. 1). The interphase nuclei were of the semi-reticulate type, being uniform among the accessions. The chromosomal condensing patterns observed in prophase to prometaphase revealed earlier proximal condensing regions and later condensing of distal chromosome arm portions (Fig. 1a, c).

Only one pair of satellited chromosomes was observed in all evaluated accessions (Fig. 2), with variations in the size and consequently the satellite types. Three of the species analyzed here (Arachis dardani, Arachis interrupta, and A. pusilla) presented larger satellites respective to type 2 (Figs. 1a, f; 2), while two species (Arachis giacomettii and Arachis sylvestris) presented small satellites classified as type 10 (Figs. 1b, e; 2).

Karyotypic formulas could be determined for all species analyzed here. A. dardani, A. pusilla, and A. interrupta presented $18 \mathrm{~m}+2 \mathrm{sm}$, with chromosomal mean length equal to $1.71,1.68$, and $1.42 \mu \mathrm{m}$, respectively, and with type 2 satellites (Table 1; Fig. 2). The species A. sylvestris and $A$. giacomettii presented moderately asymmetric karyotypes with the formula $16 \mathrm{~m}+4 \mathrm{sm}$, with chromosomal mean length 1.79 and $2.00 \mu \mathrm{m}$, respectively, and a type 10 satellited pair (Table 1; Fig. 2).

Concerning the base-specific composition of heterochromatic segments, all analyzed accessions presented CMA+/DAPI- bands in pair 4, flanking the NORs (Fig. 2), however the species A. dardani stood out by presenting a centromeric CMA+/DAPI- band in pair 3 (Figs. 1d, 2), while in A. giacomettii this band was present in pair 5 (Fig. 2). Fluorochrome staining in the analyzed accessions of $A$. pusilla revealed pericentromeric CMA+ 


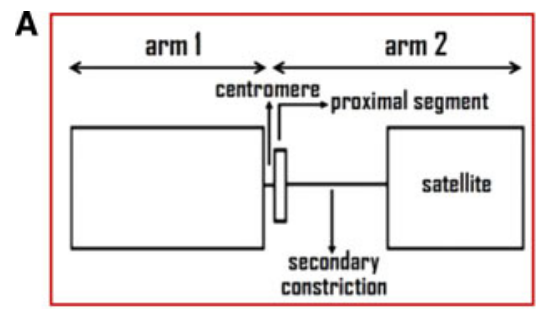

B Sat Extra-

Types nervosae

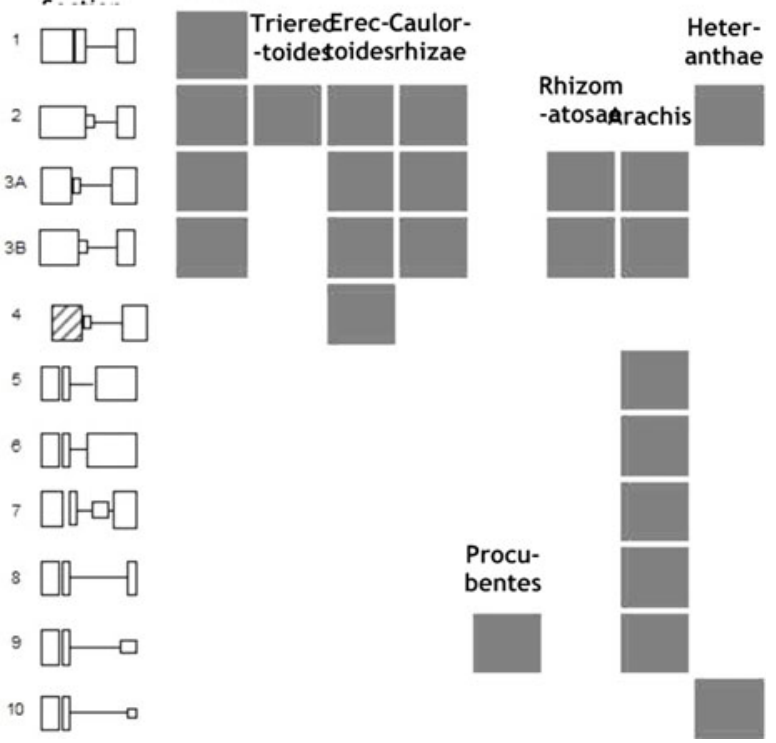

Fig. 3 a Morphology of satellited chromosome of the genus Arachis showing short arm 1 and larger arm 2 according to Fernandez and Krapovickas (1994). b Distribution of chromosome Sat-types among different Arachis sections. Adapted from Fernandez and Krapovickas (1994)

bands in all chromosomes, representing a high amount of heterochromatin revealed in Arachis, surrounded by adjacent DAPI+ bands in five chromosome pairs (Figs. 1f, 2). Small DAPI+ bands were stable in A. pusilla and unstable in the other species (data not shown). A. pusilla is also remarkable for the presence of a small negatively heteropycnotic chromosome pair (Figs. 1f, 2). Chromosomal satellites and the NORs were slightly CMA+ and DAPIin all the analyzed accessions. Figures 3 and 4 present the morphology of the chromosome SAT, the distribution of types of satellites in each section, and an overview of the changes occurring in the types of satellites during the evolution of the Arachis genus.

\section{Discussion}

In terms of chromosome number, interphase nuclei type, and chromosomal condensing pattern, the Heteranthae section can be considered uniform, and also similar to other
Arachis species previously studied (e.g., Fernandez and Krapovickas 1994).

The presence of a single chromosome pair with satellites located distally in the short arms that we observed here is also a conserved feature within the diploid Arachis species, being also conserved in the section Heteranthae. The schemes presented here in Figs. 3 and 4 show an overview of the chromosome SAT conservation along with what happened to this chromosome during the evolution of species in each section. Sometimes the simple analysis of the chromosome SAT is sufficient for screening sections. On the other hand, through the analysis of schemes outlined in this work, we can, for example, designate the section Extranervosae as the most primitive because the species possess only the type 1 satellite, Procubens as the most derived section with only a type 9 satellite, and Heteranthae section as an intermediary as it presents types 2 and 10 chromosome SAT. Many authors have used this parameter as a marker in the cytogenetic analysis of Arachis species (see, for example, Fernandez and Krapovickas 1994; Peñaloza 2000; Lavia and Fernández 2002).

Satellites differed only in terms of size and consequently type. Based on up to date information, the Heteranthae section includes three species bearing type 2 (larger satellites) and three species with type 10 (small) satellites. Fernandez and Krapovickas (1994) classified the satellited chromosomes into 10 different types, taking into account their relative size and position in relation to the centromere. Satellites of types 1-7 were classified as macrosatellites, while those of types 9 and 10 were regarded as microsatellites with type 8 being considered an intermediate.

Fernandez and Krapovickas (1994), Peñaloza (2000), and Lavia and Fernández (2002) analyzed A. sylvestris and observed satellite type 10, a result confirmed in the present study. Peñaloza and Valls (2005) also reported that $A$. seridoensis and $A$. interrupta present this same type of satellite. However, this observation could not be confirmed for the last species (A. interrupta), since we observed satellite type 2 for the analyzed accession; this information was also confirmed considering NOR-associated CMA+ blocks.

Regarding the satellite type of A. giacomettii, Lavia (1996) observed chromosomes with standard staining and classified them as probably being type 9 or 10 ; in the present work they were determined to be type 10, also considering fluorochrome banding patterns. Our work also confirms the previous results (Fernandez and Krapovickas 1994) for A. dardani and A. pusilla, in which satellite type 2 was reported for both taxa.

Fernandez and Krapovickas (1994) suggested an evolutionary path for the species from this genus, where translocation events or inversions were related to the diversity of chromosomal satellite type. Those from types 2 
Fig. 4 Overview of chromosome SAT showing the changes during the evolution of the Arachis sections

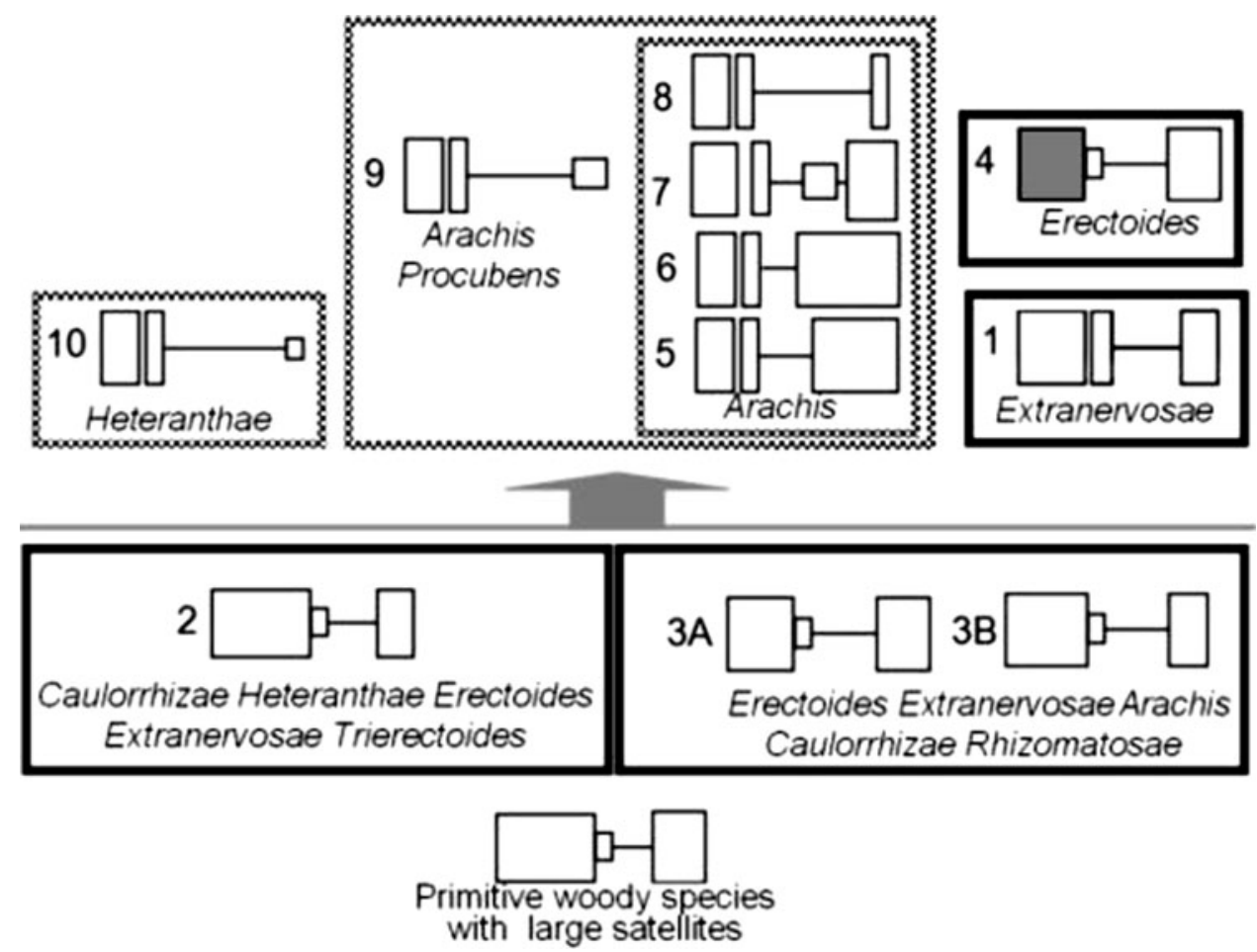

and 3 were the earliest, as they are present in most of the species and sections of the genus. Still based on the evolutionary context, Peñaloza and Valls (2005) suggested that an increase in the karyotype asymmetry gives an idea of the evolutionary direction with asymmetric satellited chromosomes (types 8-10) being most derived. For all the analyzed species, the karyotypes were moderately asymmetric. Mean length of the larger and shorter chromosomal pairs is in Table 1, with the larger represented by A. giacometti and the shorter by $A$. interrupta.

Concerning longitudinal chromosomal size, Lavia and Fernández (2002) analyzed six sections from the genus Arachis among which section Heteranthae presented one of the shorter chromosomal sizes and lower nuclear DNA content. According to Krapovickas and Gregory (1994), the greatest content of DNA was observed in the earliest species. However, Stebbins (1956) stated that there was no correlation between evolution degree and DNA content. This author preferred to accept that in a certain group of superior plants there exists a correlation between the DNA content and the ecological adaptation. When exploring with conventional staining, it was not possible to visualize the secondary constrictions of the chromosomes studied. Nevertheless, it is possible to associate the chromosomal morphology and the type of satellite. However, staining with silver nitrate $\left(\mathrm{AgNO}_{3}\right)$ would be satisfactory to show the secondary constrictions as performed by Berg and Greilhuber (1992) in species of Cestrum and to associate them with the NORs. Seijo and Fernandez (2003) used the secondary constriction location as one of the factors for karyotypic diversification of species from the genus Lathyrus. Concerning the base-specific composition of heterochromatic segments, all the accessions analyzed presented bands CMA+/DAPI- in pair 4, flanking the NOR, however the species $A$. dardani and A. pusilla presented a centromeric band CMA+/DAPI- in the pair 3, while in A. giacomettii this band was present in pair 5. Data regarding base-specific fluorochromes in the cells analyzed from accessions of $A$. pusilla revealed the largest amount of GC-rich heterochromatin reported in literature with centromeric bands $\mathrm{CMA}+$ at all chromosomes including the heteropycnotic pair. Small DAPI+ bands were observed in five chromosomal pairs. Probably these DAPI+ bands as observed in A. pusilla may also occur in other species, which will require alternative techniques to cause partial denaturation of chromosomal DNA such as C-band followed by CMAIDAPI staining. In addition, A. pusilla showed a negative heteropycnotic pair. This characteristic may be used as a strong marker for the recognition, characterization, and identification of species.

Chromosomal satellites and the NORs stand out weakly with the CMA, whereas they are not shown in the presence of DAPI. Such observation was carried out in the accessions of A. sylvestris and A. giacomettii. Schweizer (1976) and Sumner (1990) affirmed that the fluorochromes may differentially show the constitution of nucleotides present in the DNA segment, promoting an analysis of the constitution of regions observed which may be rich in AT, CG 
or neutral for both according to the intensity of fluorescence. Variations on the marking pattern with CMA fluorochrome have been widely described in the literature, including the proximately related species (Guerra 2000). Distribution patterns of heterochromatic regions rich in GC were used to distinguish eight types of chromosomes in species of Citrus (Carvalho et al. 2005). Guerra et al. (2000) used such banding patterns to describe species of Rutaceae affirming that quantitative and qualitative variations in the heterochromatin may be common across different populations and species. According to Berg and Greilhuber (1993), such variations are possibly associated with the loss or amplification of repetitive DNA sequences. It is suggested that the occurrence of alterations in the organization of the repetitive DNA segments and the modifications of the karyotypic composition may be observed through this staining.

Acknowledgments The authors thank Embrapa Genetic Resources and Biotechnology for the vegetal material provided to carry out this study.

\section{References}

Benko-Iseppon AM, Morawetz W (2000) Cytological comparison of Calyceraceae and Dipsacaceae with special reference to their taxonomic relationship. Cytologia 65:123-128

Berg C, Greilhuber J (1992) Cold-sensitive chromosome regions and their relation to constitutive heterochromatin in Cestrum-Parqui (Solanaceae). Genome 35(6):921-930

Berg C, Greilhuber J (1993) Cold-sensitive chromosome regions and heterochromatin in Cestrum-Aurantiacum (Solanaceae). Plant Syst Evol 185(3-4):259-273

Cai Q, Lu S, Chinnappa CC (1987) Analysis of karyotypes and Giemsa C-banding patterns in eight species of Arachis. Genome 29:187-194

Carvalho R, Soares-Filho WS, Brasileiro-Vidal AC, Guerra M (2005) The relationships among lemons, limes and citron: a chromosomal comparison. Cytogenet Genome Res 109:276-282

Deumling B, Greilhuber J (1982) Characterization of heterochromatin in different species of the Scilla siberica group (Liliaceae) by in situ hybridization of satellite DNAs and fluorochrome banding. Chromosoma 84:535-555

Fávero AP (2004) Cruzabilidade entre espécies silvestres de Arachis visando a introgressão de resistência a doenças no amendoim cultivado. 2004, 165 Área de concentração: Genética e Melhoramento de Plantas. ESALQ-SP. PhD Thesis, Universidade de São Paulo, Piracicaba, Brazil

Fernandez A, Krapovickas A (1994) Cromosomas y evolution en Arachis (Leguminosae). Bonplandia 8:187-220

Gregory WC, Gregory MP, Krapovickas A, Smith BW, Yarbrough JA (1973) Structures and genetic resources of peanuts. In: Wilson CT (ed) Peanuts-culture and uses, vol 3. American Peanut Research and Education Association, Stillwater, pp 47-134

Guerra M (1983) O uso Giemsa na citogenética vegetal—comparação entre a coloração simples e o bandeamento. Ciência Cultura 35:190-193
Guerra M (1986) Reviewing the chromosome nomenclature of Levan et al. Rev Bras Genet 9:741-743

Guerra M (2000) Patterns of heterochromatin distribution in plant chromosomes. Genet Mol Biol 23:1029-1041

Guerra M, Santos KGB, Silva AEB, Ehrendorfer F (2000) Heterochromatin banding patterns in Rutaceae-Aurantioideae-a case of parallel chromosomal evolution. Am J Bot 87(5):735-747

Husted L (1933) Cytological studies on the peanut, Arachis. I. Chromosome number and morphology. Cytologia 5:109-117

Husted L (1936) Cytological studies on the peanut, Arachis. II. Chromosome number, morphology and their application to the problem of the origin of the cultivated forms. Cytologia 7:396423

Krapovickas A, Gregory WC (1994) Taxonomia del género Arachis (Leguminoosae). Bompladia 8:1-186

Krapovickas A, Rigoni VA (1951) Estúdios citológicos en el gênero Arachis. Ver Invest Agric 5(3):289-293

Lavia GI (1996) Estudios cromosómicos en Arachis (Leguminosae). Bonplandia 9(1-2):111-120

Lavia GI (1998) Karyotypes of Arachis palustris and A. praecox (Section Arachis), two species with basic chromosome number $x=9$. Cytologia 63:177-181

Lavia GI, Fernández A (2002) Contenido de ADN nuclear en especies silvestres y cultivadas del género Arachis. Instituto de Botánica del Nordeste (IBONE), Facultad de Cs. Agrarias, UNNE, Corrientes, Argentina

Lima JGA, Peñaloza APS, Valls JFM, Santos S (2002) Caracterização citogenética de espécies brasileiras de Arachis (Leguminosae). In: VII EMBRAPA RECURSOS GENÉTICOS E BIOTECNOLOGIA, 2002, Brasília-DF. Embrapa Recursos genéticos e Biotecnologia

Morawetz W, Samuel MRA (1988) Karyological patterns in the Hamamelidae. In: Crane P, Blackmore S (eds) Evolution, systematics and fossil history of the Hamamelidae, vol 40. Clarendon, Oxford, pp 129-154

Peñaloza APS (2000) Citogenética das espécies silvestres do gênero Arachis (Leguminosae). $51^{\circ}$ Congresso Nacional de Botânica. Embrapa Recursos Genéticos e Biotecnologia/Sociedade Botânica do Brasil, Brasília, pp 45-49

Peñaloza APS, Valls JFM (2005) Chromosome number and satellited chromosome morphology of eleven species of Arachis (Leguminosae). Bonplandia 14(1-4):65-72

Raina SN, Mukai Y (1999) Detection of a variable number of $18 \mathrm{~S}$ 5.8S-26S and 5S ribosomal DNA loci by fluorescent in situ hybridization in diploid and tetraploid Arachis species. 59 42:52-59

Santos RC, Melo Filho PA, Brito SFM, Moraes JS (1997) Fenologia de genótipos de amendoim dos tipos botânicos Valência e Virgínia. Pesquisa Agropecuária Brasileira 32(6):607-612

Schweizer D (1976) Reverse fluorescent chromosome-banding with chromomycin A and DAPI. Chromosoma 58(4):307-324

Seijo JP, Fernandez A (2003) Karyotype analysis and chromosome evolution in South American species of Lathyrus (Leguminosae). Am J Bot 90(70):380-387

Stebbins GL (1956) Artificial polyploidy as a tool in plant breeding. Brookhaven Symp Biol 9:37-52

Sumner AT (1990) Chromosome banding. Unwin Hyman, London, p 434

Valls JFM (2005) Recursos genéticos do gênero Arachis. In: Cavalcanti dos Santos R (ed) O agronegócio do amendoim no Brasil. Embrapa Algodão, Campina Grande, pp 45-69

Valls JFM, Simpson CE (2005) New species of Arachis (Leguminosae) from Brasil, Paraguay and Bolivia. Bonplandia 14(1-2):35-63 